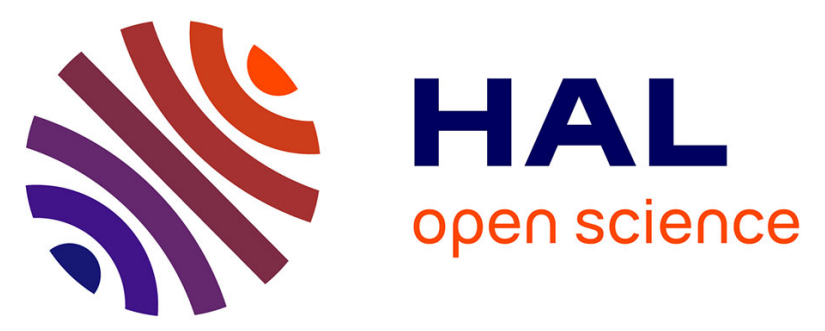

\title{
Four familial ALS pedigrees discordant for two SOD1 mutations: Are all SOD1 mutations pathogenic?
}

Ansgar Felbecker, William Camu, Paul Valdmanis, Anne-Dorte Sperfeld, Stefan Waibel, Peter Steinbach, Guy A. Rouleau, Albert C. Ludolph, Peter Munch Andersen

\section{To cite this version:}

Ansgar Felbecker, William Camu, Paul Valdmanis, Anne-Dorte Sperfeld, Stefan Waibel, et al.. Four familial ALS pedigrees discordant for two SOD1 mutations: Are all SOD1 mutations pathogenic?. Journal of Neurology, Neurosurgery and Psychiatry, 2010, 81 (5), pp.572. 10.1136/jnnp.2009.192310 . hal-00557419

\section{HAL Id: hal-00557419 \\ https://hal.science/hal-00557419}

Submitted on 19 Jan 2011

HAL is a multi-disciplinary open access archive for the deposit and dissemination of scientific research documents, whether they are published or not. The documents may come from teaching and research institutions in France or abroad, or from public or private research centers.
L'archive ouverte pluridisciplinaire $\mathbf{H A L}$, est destinée au dépôt et à la diffusion de documents scientifiques de niveau recherche, publiés ou non, émanant des établissements d'enseignement et de recherche français ou étrangers, des laboratoires publics ou privés. 


\section{Four familial ALS pedigrees discordant for two SOD1}

\section{mutations: Are all SOD1 mutations pathogenic?}

Ansgar Felbecker ${ }^{1}$, William Camu ${ }^{2}$, Paul N. Valdmanis ${ }^{3}$, Anne-Dorte Sperfeld ${ }^{1}$, Stefan Waibel ${ }^{1}$, Peter Steinbach ${ }^{4}$, Guy A. Rouleau ${ }^{3}$, Albert C. Ludolph ${ }^{1}$, Peter M. Andersen ${ }^{1,5}$

${ }^{1}$ Department of Neurology, University of Ulm, 89081 Ulm, Germany ${ }^{2}$ Clinique du Motoneurone, Service de Neurologie, Hôpital Gui-de-Chauliac, 34295 Montpellier, France ${ }^{3}$ Center of Excellence in Neuromics, University of Montreal, Centre Hospitalier de l'Université de Montréal Research Center, Notre-Dame Hospital, H2L 4M1, Montreal, Quebec, Canada ${ }^{4}$ Institute of Human Genetics, University of Ulm, 89081 Ulm, Germany ${ }^{5}$ Department of Clinical Neuroscience, Umeå University, SE90185 Umeå, Sweden

\section{Corresponding author:}

Peter Munch Andersen

MD, D.M.Sc.

Department of Clinical Neuroscience

Umeå University

SE-901 85 Umeå

Sweden

Email: Peter.Andersen@neuro.umu.se

Ph: +46 90-785 2372 (direct)

Mobilephone: +46-70 6476913

Fax: +4690143107

\section{Key words:}

Amyotrophic lateral sclerosis; SOD1 mutation; Genetic counselling; Predictive testing; Epigenetic

Word count: text 3530 , abstract 245 


\section{Abstract}

Background: One-hundred and fiftythree mutations in the $\mathrm{Cu} / \mathrm{Zn}$ superoxide dismutase (SOD1) gene have been claimed to be associated with amyotrophic lateral sclerosis (ALS) in familial and sporadic ALS in an autosomal dominant or autosomal recessive pattern with complete or reduced penetrance. We now report four ALS pedigrees from Finland, France, Germany and Sweden with either the D90A and E100K SOD1 mutations in some but not all affected members. After re-collecting of DNA, the non-segregation of the SOD1 mutations with disease were confirmed by three independent laboratories using different PCR primers: While some of the affected patients carry SOD1 mutations, other affected family members have two wildtype/normal SOD1 genes. In addition, some unaffected members within the same families are carriers of SOD1 gene mutations. To exclude other known genetic causes, we ruled out mutations within the genes coding for VAPB, ANG, TDP43, FUS and DCTN1 in affected individuals in the four pedigrees. Conclusions: We find that the D90A and E100K SOD1 gene mutations found in some patients are not the exclusive cause of ALS in these pedigrees. Whether this is also the case for the other 151 SOD1 mutations reported in ALS pedigrees is unknown. The findings have consequences for genetic testing in clinical practise when diagnosing ALS and for genetic counselling in ALS. Some SOD1 mutations may be part of an oligo- or epigentic pattern of inheritance. Such a pattern of inheritance may model other oligoor polygenetic traits responsible for other forms of ALS. 


\section{Introduction}

A familial disposition for amyotrophic lateral sclerosis (FALS) is reported by $4-13 \%$ of all ALS patients. Mutations in the Cu/Zn superoxide dismutase (SOD1) gene on chromosome $21 \mathrm{q} 22.1$ are found in $12-23 \%$ of FALS and $2-3 \%$ of sporadic ALS (SALS) (1). The SOD1 gene consists of five exons coding for a conserved polypeptide sequence of 153 amino acids. It is constitutively and ubiquitously expressed in all cells in the cytosol, nucleus and mitochondria. In 1993, Rosen et al. reported the presence of 11 SOD1 gene missense mutations segregating with familial ALS in 13 pedigrees (2). Since then, 153 mutations in the SOD1 gene have been claimed to be associated with ALS (1). It is believed that the SOD1 mutations causes neurodegeneration by a gained novel cytotoxic function. Despite intensive research no unique metabolomic biomarker for ALS caused by SOD1 mutations has been found and the molecular disease mechanism remains enigmatic. A large number of studies have compared the physical, cellular and biochemical properties of the SOD1 mutations as well as clinical characteristics of the patients carrying them, without a common denominator having been found. An explanation for this may be that many SOD1 mutations have only been found in a single individual in one or two pedigrees making it impossible to ascertain pathogenicity. The evidence that SOD1 mutations are pathogenic is based on four different lines of indirect evidence. Twenty of the 153 mutations can be claimed to be pathogenic based on linkage analysis performed in FALS-pedigrees where DNA samples were available from several individuals. Twenty-one mutations can be argued to be pathogenic based on population genetic evidence with the finding of several ALS patients with the same mutation in one large population, or the same mutation has been found in many different populations and is absent or rare among unaffected adult members in the same populations. Several mutations are in the same codon in the SOD1 gene 
suggesting that mutations in these codons may be pathogenic ("hot spot evidence"). Nine codons of the SOD1 gene contain three or more missense mutations for a total of 31 mutations. Ten mutations have been shown to cause a motor neuron disease phenotype when expressed in transgenic rodents (1). Using these four indirect methods for ascertainment of pathogenicity, only 55 of the 153 mutations reported in ALS patients can with some justification be claimed to be pathogenic.

Among the first mutations reported was the GAA to AAA DNA transition in codon 100 (3), resulting in a substitution of glutamate by lysine and the aminoacid change is denoted E100K. The 41 affected members of this African-American family in which the E100K mutation was first reported showed a slow disease progression with a median survival of 20 years. The initial report does not contain information on how many individuals were found to carry the E100K mutation and if the K100 allele cosegregated with disease (4).

The GAC to GCC DNA transversion in codon 90 mutation results in a substitution of aspartic acid for alanine and is denoted D90A. It was first discovered in 18 ALS patients from four Swedish and Finnish ALS pedigrees (5). The patients were all homozygous for the D90A mutation and the pedigrees were in accordance with inheritance as a recessive trait. D90A-homozygous patients showed a rare form of ALS with insidious onset always in the lower limbs with slow progression to the upper limbs and later bulbar innervated skeletal muscles with a mean survival time of 14 years (6). Prior to developing paresis, many patients presented with a months long phase with burning aching pain in the lower back, hip and/or knee regions, heat sensations and gait disturbance. This rather atypical phenotype has later been confirmed in D90A-homozygous ALS patients from Canada, France, Germany, Italy, Norway, Portugal, Russia, Spain, Switzerland, Turkey and the US. D90Ahomozygous ALS patients with other phenotypes have not been reported. The D90A 
mutation is the most common identified cause of ALS known worldwide. In all reported pedigrees with D90A homozygous ALS patients, the pattern of inheritance breeds true, that is no pedigree in which both D90A homozygous and D90A heterozygous individuals develop ALS has been reported worldwide. However, a few pedigrees in which D90A heterozygous individuals developed ALS have also been reported in Finland, Belgium, Belorussia, England, France, Holland, Italy, Norway, Sweden, U.S.A. (5, 7-10). Contrasting the uniform phenotype found in D90Ahomozygous ALS patients worldwide, the clinically affected D90-heterozygotes presented with variable forms of ALS including bulbar onset, upper limb onset and fast progression, Vulpian-Bernhard's variant of bibrachial ALS and lower limb onset with fast progression $(5,7,11,12,13)$. At present, five different modes of inheritance have been reported for SOD1 gene mutations: Dominant inheritance with complete penetrance, dominant inheritance with reduced disease penetrance, recessive inheritance, compound heterozygosity (14), and a single case of de novo mutation with the H80R SOD1 mutation (15). The probability of disease development in FALS rises with every decade and is $90 \%$ at the age of 70 years for SOD1 mutations with complete penetrance. The mean age of onset is $47-50$ years (16). Twenty-four SOD1 gene mutations have been associated with reduced disease penetrance and reports of healthy individuals carrying SOD1 mutations within affected families have been attributed to low disease penetrance (17). The opposite, patients with ALS without a SOD1 gene mutation in pedigrees with SOD1 positive affected family members in the same kindred have not been observed. We here report four pedigrees in which some ALS patients carry a SOD1 gene mutation (D90A, E100K) while other ALS patients carry two SOD1 wild-type ("normal") alleles. 


\section{Results}

The pedigrees of families 1 and 2 (figures 1a,b) suggest an autosomal dominant and those of families 3 and 4 (figures 1c,d) an autosomal recessive mode of inheritance. The results of the SOD1 genotype analysis are listed in table 1. There was complete concordance between the three different laboratories. These data show segregation of an $\mathrm{E} 100 \mathrm{~K}$ variant in families 1 and 2, but no co-segregation with the disease. In family 1 from Germany, DNA was available from 5 of the 14 identified ALS patients. DNA analysis showed three of the 5 tested ALS patients in this family (VI-3, VII-1 and VII-5) to be heterozygous for the E100K variant, whereas the other two affected members (VI-23 and VII-8) carry two normal E100 SOD1 alleles. There were no clinical or neurophysiological differences between the three ALS patients heterozygous for the E100K variant and the two ALS patients who did not carry an E100K allele (table 1). Among the 20 tested unaffected members of this family three (VII-7, VII-10, VIII-1; aged 24, 33 and 42 years, respectively) were found to carry the E100K allele.

In family 2 from France, DNA was available from 3 of 7 ALS patients. DNA analysis showed two of the three to be heterozygous for the E100K SOD1 allele (IV-2, V-1), whereas the third ALS patient (III-8) carries two normal E100 SOD1 alleles. DNA is not available from III-9, the affected sister of III-8, but her unaffected son does not carry the E100K allele. Unfortunately, DNA is not available from IV-5, the affected cousin of IV-2, but her unaffected 50 year old son is heterozygous for the $\mathrm{E} 100 \mathrm{~K}$ SOD1 allele.

In family 3 from Finland, the three patients presenting with slowly evolving paresis beginning in the lower limbs were found to be homozygous for the D90A SOD1 allele, while the two patients with different phenotypes were found not to carry a mutant SOD1 allele. None of the five individuals found to be heterozygous for the 
D90A allele and of the two with normal SOD1 alleles have shown any symptoms or signs of ALS.

In family 4 from Sweden, the affected siblings III-12, III-22 and III-25 were found to be homozygous for the D90A SOD1 allele. Clinically and neurophysiologically (EMG, MEP), their cousin III-10 show the same slowly evolving phenotype as the D90Ahomozygous patients in this family and in family 3 , but III-10 carries two normal SOD1 alleles.

Haplotype analysis of family 1 indicated that the affected individuals that carry the $100 \mathrm{~K}$ allele have one clear segregating haplotype and that this is distinct from a shared haplotype among affected individuals who do not have the $100 \mathrm{~K}$ allele. This was similar to the scenario in family 2 . Individuals with the $100 \mathrm{~K}$ allele had one segregating haplotype, while those with the 100E/E genotype had a different haplotype. In addition, none of the haplotypes identified in family 1 matched those from family 2 indicating that the two families are not closely related (Supplement online figures 2 and 3).

Testing for other genes reported in FALS revealed no mutations in the ALS patients in these four pedigrees. Interestingly, an unaffected married-in spouse and her unaffected daughter in family 2 both carry a P20S missense mutation in the TDP43 gene as well as a silent C159T variant in the DCTN1 gene. We found no other mutations in these four families. 


\section{Discussion}

Since 1993, 153 mutations in the SOD1 gene have been associated with ALS. All have been presumed to be pathogenic, no benign variants have been found in the highly conserved ubiquitiously expressed SOD1 in humans or in animals. The present analysis of four ALS families for SOD1 mutations revealed two SOD1 mutations that do not co-segregate with the disease. While some affected members were found to be either heterozygous for the E100K SOD1 allele (families 1 and 2) or homozygous for the D90A alleles of the SOD1 gene (families 3 and 4), other patients within the same family carried two normal SOD1 alleles. In addition, we found adult E100K heterozygotes among unaffected members of these families. The results raise the question whether or not the $\mathrm{E} 100 \mathrm{~K}$ and D90A are pathogenic and contribute to the disease in these families.

There is strong evidence that the D90A SOD1 gene mutation causes motor neuron degeneration from genetic studies of FALS pedigrees including linkage analysis (5, $13,18)$, from human epidemiological studies $(6)$ as well as from expression of the mutant D90A allele in transgenic rodents (19). On the other hand, D90A is a common SOD1 variant in the northern Scandinavian population, where as many as $5 \%$ of the general population is heterozygous for the D90A allele (6). Though ALS is a rare condition with a life-time risk of approximately 1:300-1:450 (20), one explanation for our findings in families 3 and 4 is the co-incidental rare intermarriage of FALS pedigrees with different disease causing genes. The two affected siblings III-4 and III10 in family 4 may be recessive for an as yet unknown gene or their disease may have environmental or epigenetic causes. The rare occurrence of two true sporadic ALS cases in both families 3 and 4 cannot be excluded.-The two ALS patients III-17 and IV-14 in family 3 both presented with phenotypes very different from the classical recessive D90A phenotype of the three D90A SOD1 homozygous siblings in the 
same family. Both developed definite ALS according to the El Escorial criteria. The diagnosis of ALS in III-17 and IV-14 in family 3 and of III-4 and III-10 in family 4 were supported by EMG and nerve conduction studies as well as repeated examinations by experienced neurologists making false-positive diagnosis less likely. Unfortunately, autopsies were not performed on III-17 or IV-14 in family 3 or III-4 in family 4 (III-10 is still alive).

While the findings in families 3 and 4 could be due to chance, the finding in family 1 of different SOD1 genotypes in the two affected sisters VII-5 and VII-8 - confirmed by repeated re-sampling and re-analysis and by different laboratories using different methods - is difficult to explain. A haplotype study showed that they are members of the same family with no evidence of illegitimacy and that the patients carries two different SOD1 gene alleles (supplemental figure 2 online). VII-8 and VI-23 have undergone repeated clinical and neurophysiological examinations by different clinicians with similar results, making it unlikely that they are false-positive phenocopies.

In family 2, III-8 could be a FALS case not caused by a SOD1 or other known gene mutation. Though statistically unlikely, we cannot absolutely rule out the possibility that III-8 and III-9 have inherited an unknown gene or genes from one or both of their parents, even though their parents did not exhibit any signs of disease until their death at the age of 53 and beyond 80 , respectively.

How SOD1 gene mutations cause focal onset in one myotome with successive spread to adjacent myotomes is unknown despite extensive research. Some authors favour a heterogenous, probably polygenetic cause of the disease, with mutant SOD1 being only one contributor in a cascade of effects (21). The collective evidence suggests that SOD1 mutations result in unstable SOD1 polypeptides which form insoluble (micro?) oligo-aggregates in the cytosol and possibly also in the nucleus 
and mitochondria in neurons and other cells in the CNS. To explain the sometimes rapid spread of neurodegeneration from one group of cells to neighbouring cells in adjacent segments of the spinal cord, it has been proposed that the mutant SOD1 polypeptide may have gained prion-like properties $(22,23)$. Though this has never been proven, if mutant SOD1 has gained the properties of a transmissible prion-like agent, such an epigenetic phenomena may explain the occurrence of ALS in individuals without SOD1 gene mutations as found in these four pedigrees. The recent reports of SOD1-positive cytoplasmic inclusions in spinal cord motor neurons not only in ALS patients with SOD1 gene mutations but also in patients without such mutations support the hypothesis that wildtype SOD1 may play a pathogenic role (24).

Besides the two FALS pedigrees with the E100K SOD1 gene mutation presented here, only one other FALS-family with this mutation has been reported and it is unknown how many ALS patients were DNA tested in this family, and if any were found to carry two normal SOD1 genes (3). Reportedly, 41 members of this AfroAmerican-family have developed ALS with a phenotype similar to the French and German families described here (4).

Our findings emphasize the importance of not only in a research setting but also in clinical pratise to collect DNA-samples and analyze all affected family members for a mutation, even after getting one or more mutation results. This is all the more important with a view to be able to provide genetic counselling and offer reliable presymptomatic and predictive genetic testing of asymptomatic individuals in FALS families. Even though several members of the reported families share a SOD1 mutation which is thought to cause the disease in other families, we are unsure of the pathogenic nature of the E100K SOD1 mutation. The same may hold true for some of the other SOD1 mutations previously identified upon genetic testing of individuals 
selected for the presence of an ALS phenotype. At present, we can not provide counselling to unaffected members of these families.

\section{Materials and Methods}

\section{Kindreds and clinical phenotypes}

The four pedigrees are shown in figures 1a,b,c,d and the clinical features are summarized in table 1 . The four families were identified as part of screening for SOD1 gene mutations in FALS pedigrees. Genealogical investigations were performed using public records, medical charts and death certificates.

Family 1 (figure 1a) is a German family comprising 87 members, 14 of whom reportedly had ALS. Complete clinical data is available from seven of them (V-12, VI2, VI-3, VI-23, VII-1, VII-5, VII-8). In generation V, the second clinically affected generation, five siblings were reported to have ALS. All of them died between the age of 44 and 60 after a slow disease progression for 10 to 20 years. One brother died at the age of 21 in the war, a sister did not show symptoms of ALS until her death at the age of 85 . The father IV-2 of these siblings suffered from symptoms suggesting the diagnosis of ALS: He was reported to have pareses in his legs until his death at the age of 49 due to respiratory problems. His wife IV-3 died at the age of 79 from cancer. VI-2, VI-3 and VI-23 experienced progressive weakness of distal muscles in the lower (VI-2) and upper (VI-3, VI-23) extremities around the age of 30. They showed a disease progression over a period of more than 30 years with slowly evolving tetraparesis, predominant signs of the lower motor neuron and late bulbar involvement. VI-3 died at the age of 65 , and autopsy revealed ubiquitine-positive inclusions mainly in the precentral region of the motor cortex and only mild degeneration of the pyramidal tract. VII-1, VII-5 and VII-8 were diagnosed with ALS at the age of 38,40 and 45 , respectively. All of them show a slowly progressive 
disease with mild tetraparesis, clinical signs of upper and lower motor neuron lesions and no bulbar involvement.

Family 2 (figure 1b) is a French family comprising 63 individuals, 10 of whom have developed ALS. Complete clinical data is available from six (III-1, III-8, III-9, IV-2, IV$5, \mathrm{~V}-1)$. The site of onset was bulbar in III-8, upper limb in II-2 and lower limb in 5 cases (III-1, III-9, IV-2, IV-5 and V-1), the site being unknown for three patients. ALS was of slow evolution in all patients but one (range 2 to 10 years). The patient with the fastest progression (III-8) had dysphonia and dysarthria by the age of 70 and died 2 years later. Five patients (III-1, III-4, IV-2, IV-5 and V-1) are children and grand children of patient II-2, their father II-3 did not develop ALS and died after the age of 80. Patient $\mathrm{V}-1$ is alive, she initially complained of a right foot drop like her mother. The unaffected person II-6 had 4 children, of whom 3 (III-5, III-8 and III-9) developed ALS. II-6 died at the age of 53 in a car accident, II-7 did not show symptoms of motor neuron disease until her death after the age of 80 .

In Family 3 (figure 1c) from north-eastern Finland five individuals with ALS have been found: Three of seven siblings have developed leg-onset ALS and were found to be homozygous for the D90A SOD1 allele. All three showed long survival times (table 1). Three other unaffected siblings and the mother were found to be heterozygous for the D90A allele. The father III-9 of the D90A homozygous ALS patients had a maternal cousin III-17, who at the age of 54 years developed ALS beginning with symptoms in the left hand. III-17 in turn had a nephew IV-14 who developed bulbaronset ALS at age 49 dying from respiratory failure at age 52 . In both III-17 and IV-14 the diagnoses of ALS were made after repeated clinical examinations and EMG and NCV tests. Both III-17 and IV-14 fulfilled the El Escorial criteria for ALS. Unfortunately, autopsy was performed in neither of them. III-16 was found to be carrying two normal SOD1 alleles. 
In Family 4 (figure 1d) from northern Sweden five cousins have developed ALS, the clinical details are summarized in table 1 . Three affected siblings (III-12, III-22, III-25) are homozygous for the D90A SOD1 gene mutation and all three show the classical phenotype of D90A homozygous ALS patients (6). Two of six other unaffected siblings were found to be heterozygous for the D90A allele. An affected cousin of the three, III-10, is homozygous for the wild-type SOD1 allele as are the unaffected adult children of his deceased sister III-4 (no sample available) implying that III-4 can not have been homozygous for the D90A allele. While III-10 have shown an ALSphenotype reminiscent of his D90A-homozygous cousins and over the years have undergone similar repeated examinations with EMG and MEP as his cousins, III-4 had a more rapid disease course and died of respiratory failue two years after onset. III-4 also suffered from other internal conditions and declined treatment with PEG, ventilator and riluzole.

Methods. With informed consent and adhering to the Declaration of Helsinki (25), venous blood was drawn into EDTA-containing vacuum tubes from affected and unaffected individuals marked with an asterisk in the pedigrees (Figures 1a,b,c,d). Blood was collected at least twice from the key individuals in the four pedigrees, to reduce the possibility of mislabelling of tubes. Genomic DNA was extracted from leucocytes using standard procedures. Polymerase chain reaction (PCR) amplification of all five exons of the SOD1 gene and at least 30-50bp of flanking intronic sequences was performed using different primer sets and conditions in the laboratories in Germany, Canada and Sweden (Supplemental tables 2 and 3 online). Family 1 was initially analyzed in Germany, family 2 in France and Canada, and families 3 and 4 in Sweden. Later, blinded coded DNA samples from all four pedigrees were distributed to the other involved laboratories and re-sequenced. All four pedigrees were thereby analyzed for SOD1 gene mutations at least three times. 
The patients were additionally tested for mutations in other genes associated with ALS: VAPB, ANG, TDP43, FUS and the p150 subunit of dynactin (DCTN1). These analyses were performed in a blinded fashion in at least one of the involved laboratories as described elsewhere (26-29).

For haplotype analysis of families 1 and 2, six markers were selected that spanned the SOD1 locus (D21S272, D21S213, D21S1270, D21S263, D21S224 and D21S219). PCRs were performed incorporating radiolabeled $\alpha^{3}{ }^{35}$ S-dATP, and were loaded on $6 \%$ denaturing polyacrylamide gels. Allele sizes and frequencies were obtained from the CEPH database (www.ceph.fr). 


\section{Acknowledgements}

We are indebted to the patients and their families for their participation in this project.

This project has been generously supported by the Kempe Foundations, the Swedish

Brain Power Foundation, the Swedish Brain Research Foundation, the Hållstens

Research Foundation, the Swedish Medical Society and the Björklund Foundation for

ALS Research, the Ulla-Carin Lindquist Foundation, and the Swedish Association for the Neurologically Disabled. We are also grateful to the Association Française contre les Myopathies and Association pour la Recherche contre la Sclérose Latérale Amyotrophique for their financial support.

\section{Conflicts of interest}

None of the authors has got any conflicts of interest to declare.

The Corresponding Author has the right to grant on behalf of all authors and does grant on behalf of all authors, an exclusive licence (or non-exclusive for government employees) on a worldwide basis to the BMJ Publishing Group Ltd and its Licensees to permit this article (if accepted) to be published in Journal of Neurology, Neurosurgery \& Psychiatry and any other BMJPGL products to exploit all subsidiary rights. 


\section{References}

1. Andersen, P.M. Amyotrophic lateral sclerosis associated with mutations in the CuZn superoxide dismutase gene. Current neurology and neuroscience reports 2006;6:37-46.

2. Rosen, D.R., Siddique, T., Patterson, D., Figlewicz, D.A., Sapp, P., Hentati, A., Donaldson, D., Goto, J., O'Regan, J.P., Deng, H.X. et al. Mutations in $\mathrm{Cu} / \mathrm{Zn}$ superoxide dismutase gene are associated with familial amyotrophic lateral sclerosis. Nature 1993;362:59-62.

3. Siddique, T., Nijhawan, D. and Hentati, A. Molecular genetic basis of familial ALS. Neurology, 1996;47:S27-34; discussion S34-35.

4. Gaudette, M., Hirano, M. and Siddique, T. Current status of SOD1 mutations in familial amyotrophic lateral sclerosis. Amyotroph Lateral Scler Other Motor Neuron Disord 2000;1:83-89.

5. Andersen, P.M., Nilsson, P., Ala-Hurula, V., Keranen, M.L., Tarvainen, I., Haltia, T., Nilsson, L., Binzer, M., Forsgren, L. and Marklund, S.L. Amyotrophic lateral sclerosis associated with homozygosity for an Asp90Ala mutation in CuZn-superoxide dismutase. Nature genetics 1995;10:61-66.

6. Andersen, P.M., Forsgren, L., Binzer, M., Nilsson, P., Ala-Hurula, V., Keranen, M.L., Bergmark, L., Saarinen, A., Haltia, T., Tarvainen, I. et al. Autosomal recessive adult-onset amyotrophic lateral sclerosis associated with homozygosity for Asp90Ala CuZn-superoxide dismutase mutation. A clinical and genealogical study of 36 patients. Brain 1996;119:1153-1172.

7. Robberecht, W., Aguirre, T., Van den Bosch, L., Tilkin, P., Cassiman, J.J. and Matthijs, G. D90A heterozygosity in the SOD1 gene is associated with familial and apparently sporadic amyotrophic lateral sclerosis. Neurology 1996;47:1336-1339.

8. Jackson, M., Al-Chalabi, A., Enayat, Z.E., Chioza, B., Leigh, P.N. and Morrison, K.E. (1997) Copper/zinc superoxide dismutase 1 and sporadic amyotrophic lateral sclerosis: analysis of 155 cases and identification of a novel insertion mutation. Annals of neurology 1997;42:803-807.

9. Khoris, J., Moulard, B., Briolotti, V., Hayer, M., Durieux, A., Clavelou, P., Malafosse, A., Rouleau, G.A. and Camu, W. Coexistence of dominant and recessive familial amyotrophic lateral sclerosis with the D90A Cu,Zn superoxide dismutase mutation within the same country. Eur J Neurol 2000;7:207-211.

10. Skvortsova, V.I., Limborska, S.A., Slominsky, P.A., Levitskaya, N.I., Levitsky, G.N., Shadrina, M.I. and Kondratyeva, E.A. Sporadic ALS associated with the D90A Cu,Zn superoxide dismutase mutation in Russia. Eur J Neurol, 2001;8:167-172.

11. Andersen, P.M., Sims, K.B., Xin, W.W., Kiely, R., O'Neill, G., Ravits, J., Pioro, E., Harati, Y., Brower, R.D., Levine, J.S. et al. Sixteen novel mutations in the $\mathrm{Cu} / \mathrm{Zn}$ superoxide dismutase gene in amyotrophic lateral sclerosis: a decade of discoveries, defects and disputes. Amyotroph Lateral Scler Other Motor Neuron Disord 2003;4:62-73. 
12. Mezei, M., Andersen, P.M., Stewart, H., Weber, M. and Eisen, A. Motor system abnormalities in heterozygous relatives of a D90A homozygous CuZnSOD ALS patient of finnish extraction. Journal of the neurological sciences 1999;169:49-55.

13. Parton, M.J., Broom, W., Andersen, P.M., Al-Chalabi, A., Nigel Leigh, P., Powell, J.F. and Shaw, C.E. (2002) D90A-SOD1 mediated amyotrophic lateral sclerosis: a single founder for all cases with evidence for a Cis-acting disease modifier in the recessive haplotype. Human mutation 2002;20:473.

14. Hand, C.K., Mayeux-Portas, V., Khoris, J., Briolotti, V., Clavelou, P., Camu, W. and Rouleau, G.A. Compound heterozygous D90A and D96N SOD1 mutations in a recessive amyotrophic lateral sclerosis family. Annals of neurology 2001;49:267-271.

15. Alexander, M.D., Traynor, B.J., Miller, N., Corr, B., Frost, E., McQuaid, S., Brett, F.M., Green, A. and Hardiman, O. "True" sporadic ALS associated with a novel SOD-1 mutation. Annals of neurology 2002;52:680-683.

16. Cudkowicz, M.E., McKenna-Yasek, D., Sapp, P.E., Chin, W., Geller, B., Hayden, D.L., Schoenfeld, D.A., Hosler, B.A., Horvitz, H.R. and Brown, R.H. Epidemiology of mutations in superoxide dismutase in amyotrophic lateral sclerosis. Annals of neurology 1997;41:210-221.

17. Rezania, K., Yan, J., Dellefave, L., Deng, H.X., Siddique, N., Pascuzzi, R.T., Siddique, T. and Roos, R.P. A rare $\mathrm{Cu} / \mathrm{Zn}$ superoxide dismutase mutation causing familial amyotrophic lateral sclerosis with variable age of onset, incomplete penetrance and a sensory neuropathy. Amyotroph Lateral Scler Other Motor Neuron Disord 2003;4:162-166.

18. Al-Chalabi, A. and Leigh, P.N. Recent advances in amyotrophic lateral sclerosis. Current opinion in neurology 2000;13:397-405.

19. Jonsson, P.A., Graffmo, K.S., Brannstrom, T., Nilsson, P., Andersen, P.M. and Marklund, S.L. Motor neuron disease in mice expressing the wild type-like D90A mutant superoxide dismutase-1. Journal of neuropathology and experimental neurology, 2006;65:1126-1136.

20. Johnston, C.A., Stanton, B.R., Turner, M.R., Gray, R., Blunt, A.H., Butt, D., Ampong, M.A., Shaw, C.E., Leigh, P.N. and Al-Chalabi, A. Amyotrophic lateral sclerosis in an urban setting: a population based study of inner city London. Journal of neurology 2006;253:1642-1643.

21. Polymenidou M, Cleveland DW. Motor neuron disease: The curious ways of ALS. Nature 2008;454:284-285.

22. Aggarwal, A. and Nicholson, G. Detection of preclinical motor neurone loss in SOD1 mutation carriers using motor unit number estimation. Journal of neurology, neurosurgery, and psychiatry 2002;73:199-201.

23. Ravits, J., Laurie, P., Fan, Y. and Moore, D.H. Implications of ALS focality: rostral-caudal distribution of lower motor neuron loss postmortem. Neurology 2007; 68:1576-1582.

24. Zetterstrom, P., Stewart, H.G., Bergemalm, D., Jonsson, P.A., Graffmo, K.S., Andersen, P.M., Brannstrom, T., Oliveberg, M. and Marklund, S.L. Soluble misfolded subfractions of mutant superoxide dismutase-1s are enriched in 
spinal cords throughout life in murine ALS models. Proceedings of the National Academy of Sciences of the United States of America 2007;104:14157-14162.

25. Rits, I.A. Declaration of Helsinki. Recommendations Guidings Doctors in Clinical Research. World medical journal 1964;11:281.

26. Munch, C., Sedlmeier, R., Meyer, T., Homberg, V., Sperfeld, A.D., Kurt, A., Prudlo, J., Peraus, G., Hanemann, C.O., Stumm, G. et al. Point mutations of the p150 subunit of dynactin (DCTN1) gene in ALS. Neurology 2004; 63:724726.

27. Nishimura, A.L., Mitne-Neto, M., Silva, H.C., Richieri-Costa, A., Middleton, S., Cascio, D., Kok, F., Oliveira, J.R., Gillingwater, T., Webb, J. et al. A mutation in the vesicle-trafficking protein VAPB causes late-onset spinal muscular atrophy and amyotrophic lateral sclerosis. American journal of human genetics 2004;75:822-831.

28. Greenway MJ, Andersen PM, Russ C, Ennis S, Cashman S, Donaghy C, et al. ANG mutations segregate with familial and 'sporadic' amyotrophic lateral sclerosis. Nature genetics 2006;38:411-413.

29. Neumann M, Sampathu DM, Kwong LK, Truax AC, Micsenyi MC, Chou TT, et al. Ubiquitinated TDP-43 in frontotemporal lobar degeneration and amyotrophic lateral sclerosis. Science 2006;314:130-133. 


\section{Figure Legends}

\section{Figure 1a}

Kindred of family 1 . The K100 SOD1 mutation is only present in the left part of the pedigree. Individuals that have been DNA-tested are indicated with an asterisk, the individual genotype is indicated under the symbol (E/E: two wildtype alleles, $E / K$ : heterozygous E100K mutation). Affected individuals are shown in black. VII-7, VII-10 and VIII-1 are adult healthy individuals with E100K genotype (E/K), VI-23 and VII-8 are affected individuals with wildtype genotype $(E / E)$.

\section{Figure 1b}

Kindred of family 2. The K100 SOD1 mutation is only present in the left part of the pedigree. Individuals that have been tested are indicated with an asterisk, the individual genotype is indicated under the symbol $(\mathrm{E} / \mathrm{E}$ : two wildtype alleles, $\mathrm{E} / \mathrm{K}$ : heterozygous E100K mutation). Affected individuals are shown in black. V-2 is an adult healthy individual with E100K genotype $(\mathrm{E} / \mathrm{K})$, III-8 is an ALS patient (now deceased) with the wildtype genotype $(E / E)$.

\section{Figure 1c}

Kindred of family 3. The A90 SOD1 mutation is only present in the left part of the pedigree. Individuals that have been tested are indicated with an asterisk, the individual genotype is indicated under the symbol (D/D: two wildtype alleles, D/A: heterozygous D90A mutation, A/A: homozygous D90A mutation). Affected individuals are shown in black. III-10, III-11, IV-3, IV-8 and IV-10 are healthy adult individuals with heterozygous D90A mutations (D/A), III-17 and IV-14 are affected individuals with the wildtype SOD1 genotype (D/D). 


\section{Figure 1d}

Kindred of family 4. The A90 SOD1 mutation is only present in the right part of the pedigree. Individuals that have been tested are indicated with an asterisk, the individual genotype is indicated under the symbol (D/D: two wildtype alleles, D/A: heterozygous D90A mutation, A/A: homozygous D90A mutation). Affected individuals are shown in black. III-19 and III-24 are healthy individuals heterozygous for the D90A mutation (D/A). III-10 is an affected individual with the wildtype genotype (D/D). In addition, III-4 is an affected ALS patient (now deceased) which can not have been homozygous for the A90 SOD1 mutation since her children carries two wt/wt SOD1 alleles.

\section{Supplemental figure 2}

Haplotype analysis for Family 1. For clarity, some un-genotyped individuals from figure 1a are not included on this pedigree. Note that there is a clear black haplotype which segregates with the E100K genotype, and a grey haplotype which segregates with the E100E genotype. Marker order (Mb) on chromosome 21: D21S272 (24.3); D21S213 (30.1); D21S1270 (30.6); D21S263 (31.1); SOD1 (31.9); D21S224 (32.8); D21S219 (34.0).

\section{Supplemental figure 3}

Haplotype analysis for Family 2. A black haplotype segregates with the E100K genotype in this family; however, this haplotype is distinct from that in family 1. 
Marker order (Mb) on chromosome 21: D21S272 (24.3); D21S213 (30.1);

D21S1270 (30.6); D21S263 (31.1); SOD1 (31.9); D21S224 (32.8); D21S219 (34.0).

\section{Table Legends}

\section{Table 1}

Clinical details and SOD1 genotype of key family members. Clinically unaffected persons with normal SOD1 genotype and affected persons without sufficient clinical information available are not shown, for details refer to text. ${ }^{1} \mathrm{~N}-\mathrm{N}$ indicates two wildtype alleles or normal SOD1 gene, N-E100K indicates heterozygous E100K mutation, N-D90A indicates heterozygous D90A mutation, D90A - D90A indicates homozygous D90A mutation ${ }^{2}$ diagnosis likely according to history of progressive tetraparesis ${ }^{3}$ patient alive, duration of symptoms at time of writing in brackets ${ }^{4}$ clinically not affected and alive, age at time of writing in brackets.

\section{Supplemental table 2}

PCR and sequencing primers of the centres in Ulm (Germany), Umeå (Sweden) and Montreal (Canada).

\section{Supplemental table 3}

PCR cycling conditions used in the different laboratories. 


\section{Tables}

Table 1- clinical details of the relevant members of all families

\begin{tabular}{|c|c|c|c|c|c|}
\hline $\begin{array}{l}\text { Patient } \\
\text { (Identifier) }\end{array}$ & ALS? & $\begin{array}{l}\text { Onset } \\
\text { (age) }\end{array}$ & Site of onset & $\begin{array}{l}\text { Duration } \\
\text { (years) }\end{array}$ & $\begin{array}{l}\text { SOD1 } \\
\text { gene }^{1}\end{array}$ \\
\hline \multicolumn{6}{|l|}{ Family 1} \\
\hline IV-2 & $(\text { Yes })^{2}$ & 45 & Lower limbs & 4 & No DNA available \\
\hline V-2 & Yes & 30 & Unknown & 27 & No DNA available \\
\hline V-9 & Yes & 40 & Lower limbs & 4 & No DNA available \\
\hline V-12 & Yes & 30 & Unknown & 9 & No DNA available \\
\hline VI-2 & Yes & 31 & Lower limbs & 17 & No DNA available \\
\hline VI-3 & Yes & 31 & Upper limbs & 34 & $N-E 100 K$ \\
\hline VI-23 & Yes & 28 & Upper limbs & 37 & $\mathrm{~N}-\mathrm{N}$ \\
\hline VII-1 & Yes & 38 & Upper limbs & $(5)^{3}$ & $N-E 100 K$ \\
\hline VII-5 & Yes & 39 & Upper limbs & $(5)^{3}$ & $N-E 100 K$ \\
\hline VII-7 & No & $-(42)^{4}$ & - & - & $N-E 100 K$ \\
\hline VII-8 & Yes & 45 & Upper limbs & $(5)^{3}$ & $N-N$ \\
\hline VII-10 & No & $-(34)^{4}$ & - & - & $N-E 100 K$ \\
\hline VIII-1 & No & $-(26)^{4}$ & - & - & $N-E 100 K$ \\
\hline \multicolumn{6}{|l|}{ Family 2} \\
\hline II-2 & Yes & 43 & Upper limbs & 10 & No DNA available \\
\hline III-1 & Yes & 66 & Upper limbs & 4 & No DNA available \\
\hline III-4 & Yes & 42 & Lower limbs & 6 & No DNA available \\
\hline III-5 & Yes & 45 & Unknown & 7 & No DNA available \\
\hline III-8 & Yes & 70 & Bulbar & 2 & $N-N$ \\
\hline III-9 & Yes & 28 & Lower limbs & 4 & No DNA available \\
\hline
\end{tabular}




\begin{tabular}{|c|c|c|c|c|c|}
\hline |IV-2 & Yes & 41 & Lower limbs & 10 & $N-E 100 K$ \\
\hline IV-5 & Yes & 48 & Lower limbs & 8 & No DNA available \\
\hline $\mathrm{V}-1$ & Yes & 36 & Lower limbs & $(7)^{3}$ & $\mathrm{~N}-\mathrm{E} 100 \mathrm{~K}$ \\
\hline V-2 & No & $-(50)^{4}$ & - & - & $N-E 100 K$ \\
\hline \multicolumn{6}{|c|}{ Family 3} \\
\hline III-10 & No & - & - & - & $N-D 90 A$ \\
\hline |II-11 & No & - & - & - & $N-D 90 A$ \\
\hline III-17 & Yes & 54 & Upper limbs & 2 & $N-N$ \\
\hline IV-1 & Yes & 20 & Lower limbs & $(35)^{3}$ & $D 90 A-D 90 A$ \\
\hline IV-3 & No & - & - & - & $N-D 90 A$ \\
\hline IV -5 & Yes & 32 & Lower limbs & 18 & $\mathrm{D} 90 \mathrm{~A}-\mathrm{D} 90 \mathrm{~A}$ \\
\hline IV-7 & Yes & 20 & Lower limbs & 30 & D90A - D90A \\
\hline IV-8 & No & - & - & - & $N-D 90 A$ \\
\hline IV-10 & No & - & - & - & $N-D 90 A$ \\
\hline IV-14 & Yes & 49 & Bulbar & 3 & $N-N$ \\
\hline \multicolumn{6}{|c|}{$\mid \begin{array}{l}\text { Family } 4 \\
\end{array}$} \\
\hline III-4 & Yes & 71 & lower limbs & 2 & No DNA available \\
\hline III-10 & Yes & 71 & lower limbs & $(11)^{3}$ & $\mathrm{~N}-\mathrm{N}$ \\
\hline |III-12 & Yes & 67 & lower limbs & 10 & $\mathrm{D} 90 \mathrm{~A}-\mathrm{D} 90 \mathrm{~A}$ \\
\hline |III-19 & No & - & - & - & $\mathrm{N}-\mathrm{D} 90 \mathrm{~A}$ \\
\hline |III-22 & Yes & 57 & lower limbs & 9 (autopsied) & $\mathrm{D} 90 \mathrm{~A}-\mathrm{D} 90 \mathrm{~A}$ \\
\hline III-24 & No & - & - & - & $\mathrm{N}-\mathrm{D} 90 \mathrm{~A}$ \\
\hline |III-25 & Yes & 66 & lower limbs & $(1)^{3}$ & D90A - D90A \\
\hline
\end{tabular}


table 2- PCR and sequencing primers

\begin{tabular}{|c|c|c|c|}
\hline Exon & Direction & PCR / Sequencing & Primer \\
\hline \multicolumn{4}{|c|}{$\begin{array}{l}\text { Ulm, Germany (Applied Biosystems 310, using Applied Biosystems Big Dye teminator } \\
\text { v3.1 sequencing chemistry) }\end{array}$} \\
\hline Exon & $\begin{array}{l}\text { Forward } \\
\text { Forward } \\
\text { Reverse } \\
\text { Reverse }\end{array}$ & $\begin{array}{l}\text { PCR } \\
\text { Sequencing } \\
\text { PCR } \\
\text { Sequencing }\end{array}$ & $\begin{array}{l}\text { 5-TTTTGCCATTTTCGCGTACTGCAACC-3 } \\
\text { 5-AGGTCTGGCCTATAAAG-3 } \\
\text { 5-AAAGGGTCGCGGGGGGACG-3 } \\
\text { 5-AGCGGGTCGGGAGCGGCCT-3 }\end{array}$ \\
\hline $\begin{array}{l}\text { Exon } \\
2\end{array}$ & $\begin{array}{l}\text { Forward } \\
\text { Forward } \\
\text { Reverse } \\
\text { Reverse }\end{array}$ & $\begin{array}{l}\text { PCR } \\
\text { Sequencing } \\
\text { PCR } \\
\text { Sequencing }\end{array}$ & $\begin{array}{l}\text { 5-GCTGGAGGTTCACTGGCTAG-3 } \\
\text { 5-GTGGTCAGCCTGGGAT-3 } \\
\text { 5-GGGTTTTAACGTTTAGGGGC-3 } \\
\text { 5-TGTTTATCTAACTAGGGTG-3 }\end{array}$ \\
\hline $\begin{array}{l}\text { Exon } \\
3\end{array}$ & $\begin{array}{l}\text { Forward } \\
\text { Forward } \\
\text { Reverse } \\
\text { Reverse }\end{array}$ & $\begin{array}{l}\text { PCR } \\
\text { Sequencing } \\
\text { PCR } \\
\text { Sequencing }\end{array}$ & $\begin{array}{l}\text { 5-TCTGTTCCCTTCTCACTGT-3 } \\
\text { 5-TCGTGATGCAGGTC-3 } \\
\text { 5-TCCCCTTTGGCACTTGTATT-3 } \\
\text { 5-GGGGGAAACACGG-3 }\end{array}$ \\
\hline Exon & $\begin{array}{l}\text { Forward } \\
\text { Forward } \\
\text { Reverse }\end{array}$ & $\begin{array}{l}\text { PCR } \\
\text { Sequencing } \\
\text { PCR + Sequencing }\end{array}$ & $\begin{array}{l}\text { 5-GTGTCTACTCAGTCAAGTTTTAA-3 } \\
\text { 5-GCTCATGAACTACCTTG-3 } \\
\text { 5-CGCGACTAACAATCAAAGTGA-3 }\end{array}$ \\
\hline Exon & $\begin{array}{l}\text { Forward } \\
\text { Reverse } \\
\text { Reverse }\end{array}$ & $\begin{array}{l}\text { PCR + Sequencing } \\
\text { PCR } \\
\text { Sequencing }\end{array}$ & $\begin{array}{l}\text { 5-GTTGGGAGGAGGTAGTGATTA-3 } \\
\text { 5-AGCAGAGTTGTGTTAGTTTTAG-3 } \\
\text { 5-ACATTTCTAGAGCTAGCAGG-3 }\end{array}$ \\
\hline Jme & eden & plied Biosystems 37 & $\begin{array}{l}\mathrm{XL} \text { automated fluorescent DNA sequencer, } \\
\text { or v3.1 sequencing chemistry) }\end{array}$ \\
\hline Exon & Forward & PCR + Sequencing & 5-CTCCACATTTCGGGGTTCT-3 \\
\hline
\end{tabular}




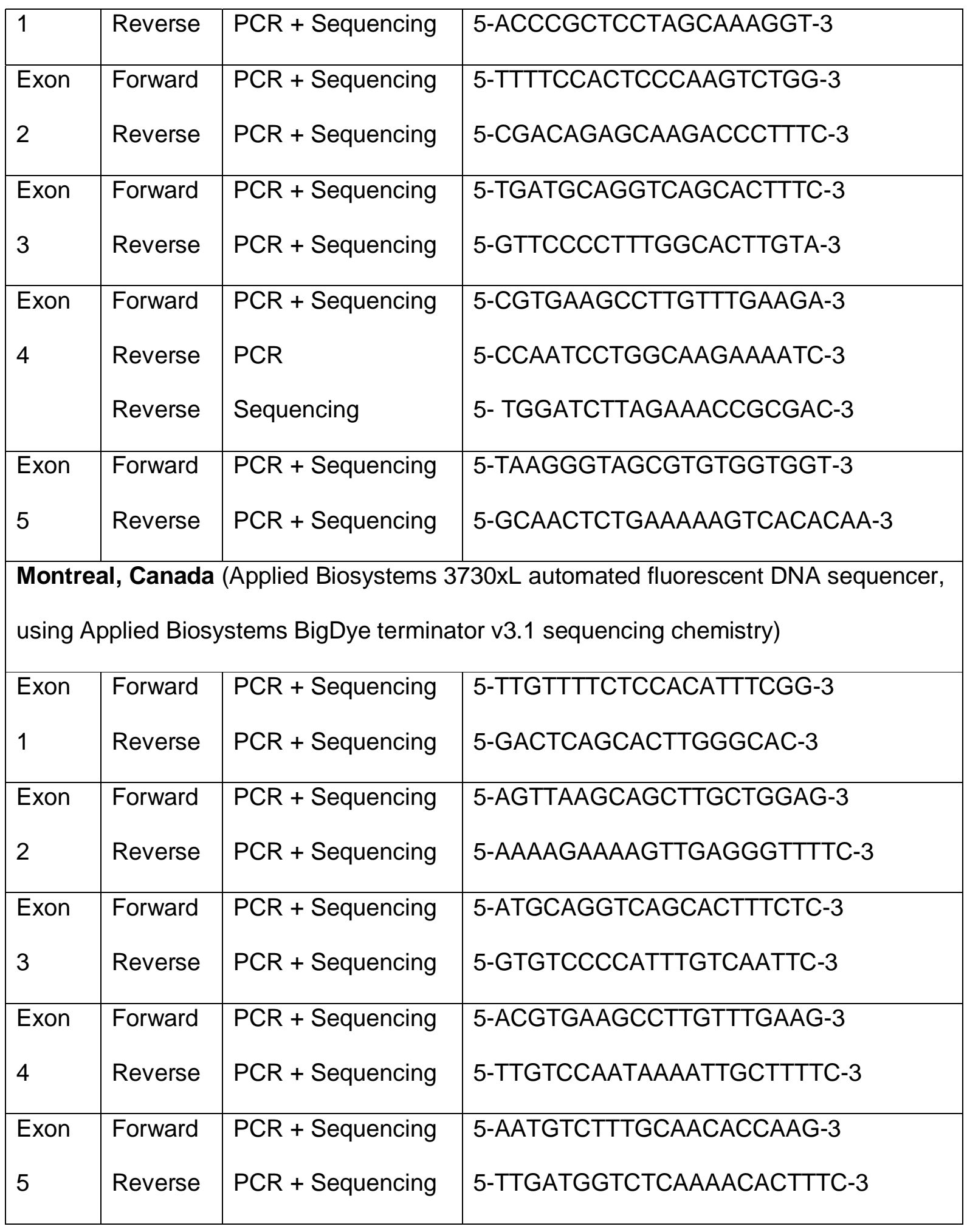


table 3 - PCR cycling conditions used in the different laboratories

\begin{tabular}{|c|c|c|c|c|c|c|c|}
\hline \multicolumn{8}{|c|}{ Ulm, Germany (GeneAmp2400) } \\
\hline \multirow{2}{*}{$\begin{array}{l}\text { Exon 1, } 2 \\
\text { and } 4\end{array}$} & $95^{\circ}$ & $5 \min$ & & & & & \multirow[b]{2}{*}{30 cycles } \\
\hline & $95^{\circ}$ & $30 \mathrm{sec}$ & $60^{\circ}$ & $45 \mathrm{sec}$ & $72^{\circ}$ & $60 \mathrm{sec}$ & \\
\hline & $72^{\circ}$ & $5 \min$ & & & & & \\
\hline & $4^{\circ}$ & $\infty$ & & & & & \\
\hline \multirow{4}{*}{$\begin{array}{l}\text { Exon } 3 \\
\text { and } 5\end{array}$} & $94^{\circ}$ & $2 \min$ & & & & & \\
\hline & $94^{\circ}$ & $30 \mathrm{sec}$ & $60,5^{\circ}$ & $45 \mathrm{sec}$ & $68^{\circ}$ & $120 \mathrm{sec}$ & 35 cycles \\
\hline & $68^{\circ}$ & $7 \min$ & & & & & \\
\hline & $4^{\circ}$ & $\infty$ & & & & & \\
\hline \multicolumn{8}{|c|}{ Umeå, Sweden (GeneAmp 9700) } \\
\hline \multirow{9}{*}{$\begin{array}{l}\text { Exon 1- } \\
5\end{array}$} & $95^{\circ}$ & $15 \min$ & & & & & \\
\hline & $94^{\circ}$ & $30 \mathrm{sec}$ & $70,3^{\circ}$ & $40 \mathrm{sec}$ & $72^{\circ}$ & $30 \mathrm{sec}$ & 2 cycles \\
\hline & $94^{\circ}$ & $30 \mathrm{sec}$ & $68,3^{\circ}$ & $40 \mathrm{sec}$ & $72^{\circ}$ & $30 \mathrm{sec}$ & 2 cycles \\
\hline & $94^{\circ}$ & $30 \mathrm{sec}$ & $66,3^{\circ}$ & $40 \mathrm{sec}$ & $72^{\circ}$ & $30 \mathrm{sec}$ & 2 cycles \\
\hline & $94^{\circ}$ & $30 \mathrm{sec}$ & $64,3^{\circ}$ & $40 \mathrm{sec}$ & $72^{\circ}$ & $30 \mathrm{sec}$ & 2 cycles \\
\hline & $94^{\circ}$ & $30 \mathrm{sec}$ & $62,3^{\circ}$ & $40 \mathrm{sec}$ & $72^{\circ}$ & $30 \mathrm{sec}$ & 2 cycles \\
\hline & $94^{\circ}$ & $30 \mathrm{sec}$ & $60,3^{\circ}$ & $40 \mathrm{sec}$ & $72^{\circ}$ & $30 \mathrm{sec}$ & 30 cycles \\
\hline & $72^{\circ}$ & $10 \mathrm{~min}$ & & & & & \\
\hline & $8^{\circ}$ & $\infty$ & & & & & \\
\hline \multicolumn{8}{|c|}{ Montreal, Canada (GeneAmp 9700) } \\
\hline \multirow{2}{*}{$\begin{array}{l}\text { Exon } 1 \\
-5\end{array}$} & $94^{\circ}$ & $5 \min$ & & & & & \\
\hline & $94^{\circ}$ & $30 \mathrm{sec}$ & $59^{\circ}$ & $30 \mathrm{sec}$ & $72^{\circ}$ & $45 \mathrm{sec}$ & 1 cycle \\
\hline
\end{tabular}




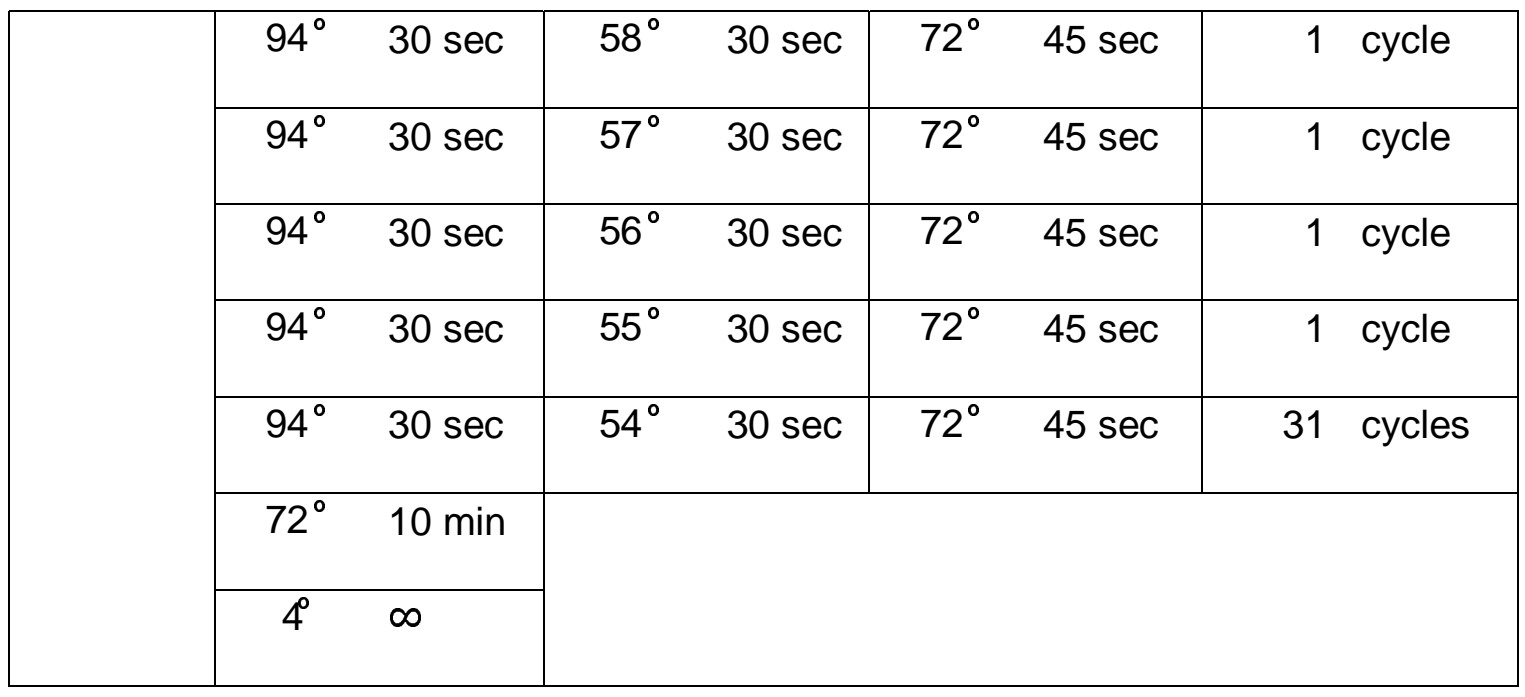


Figure 1a

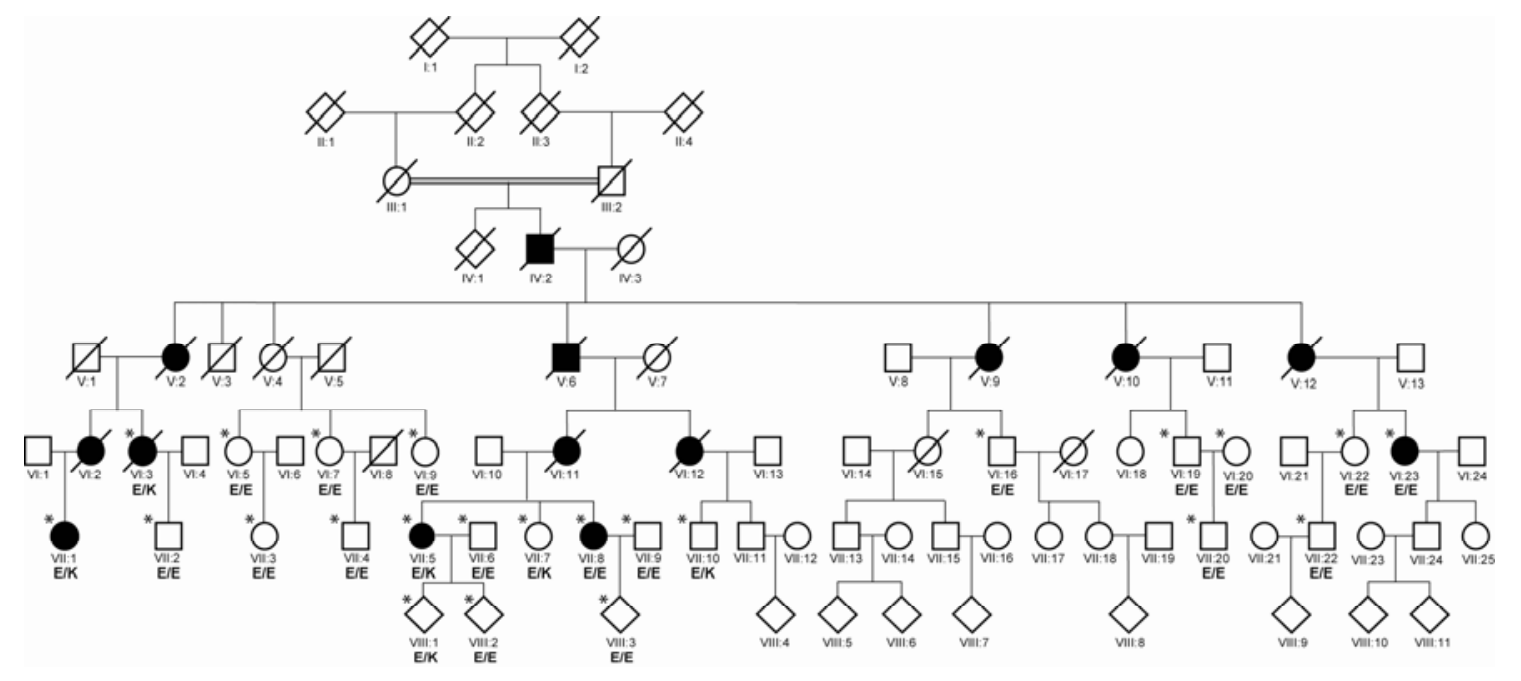

Figure 1b

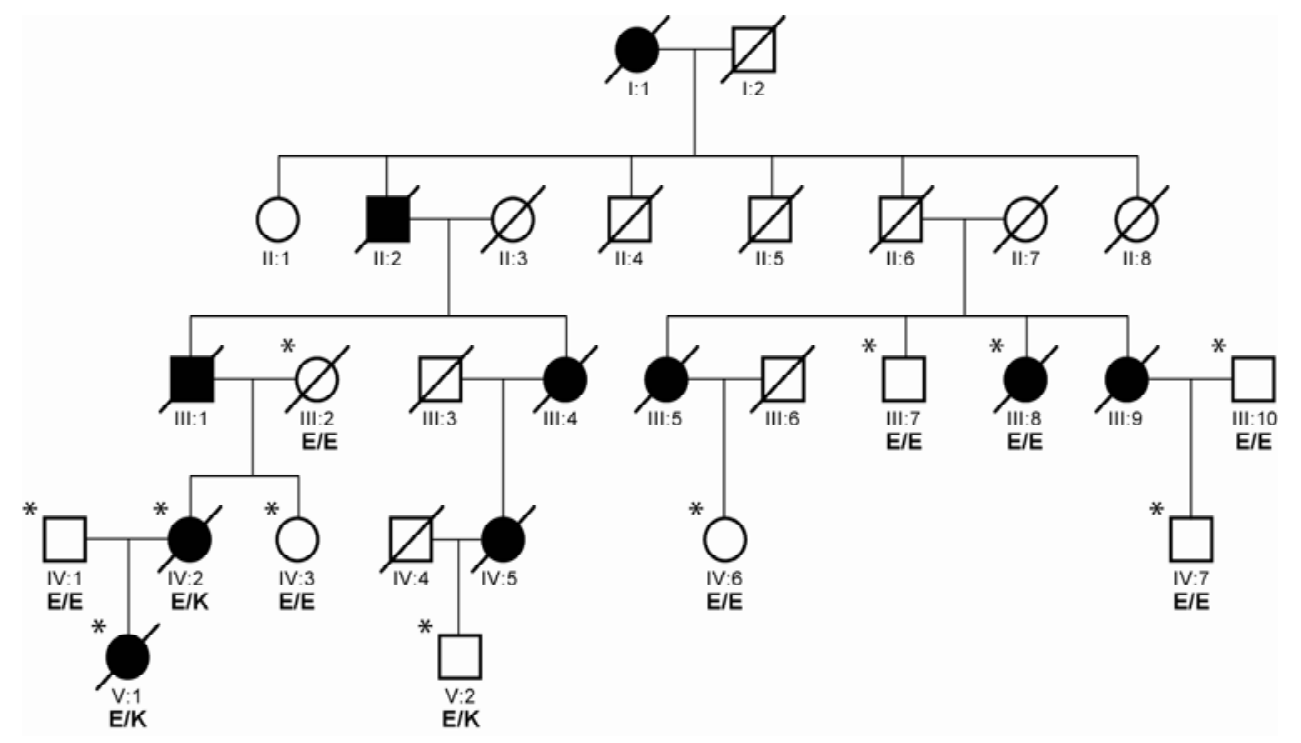


Figure 1c

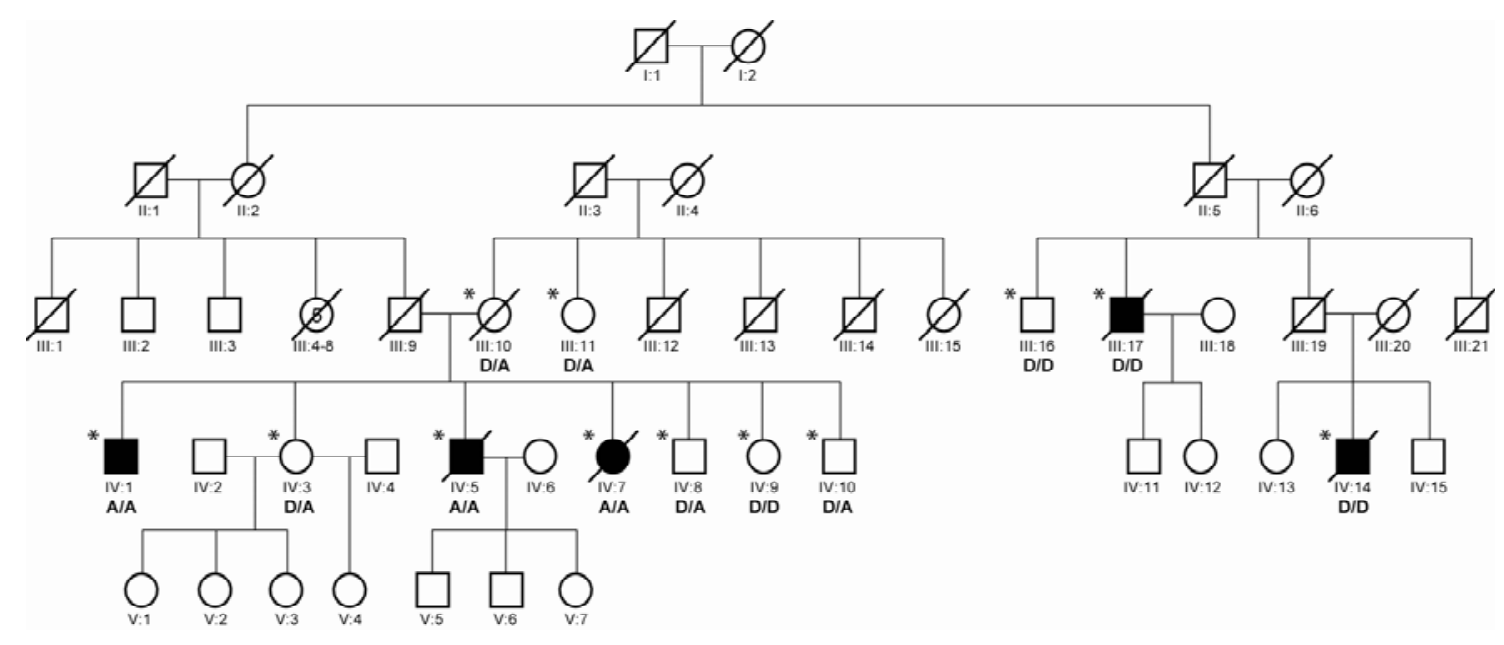

Figure 1d

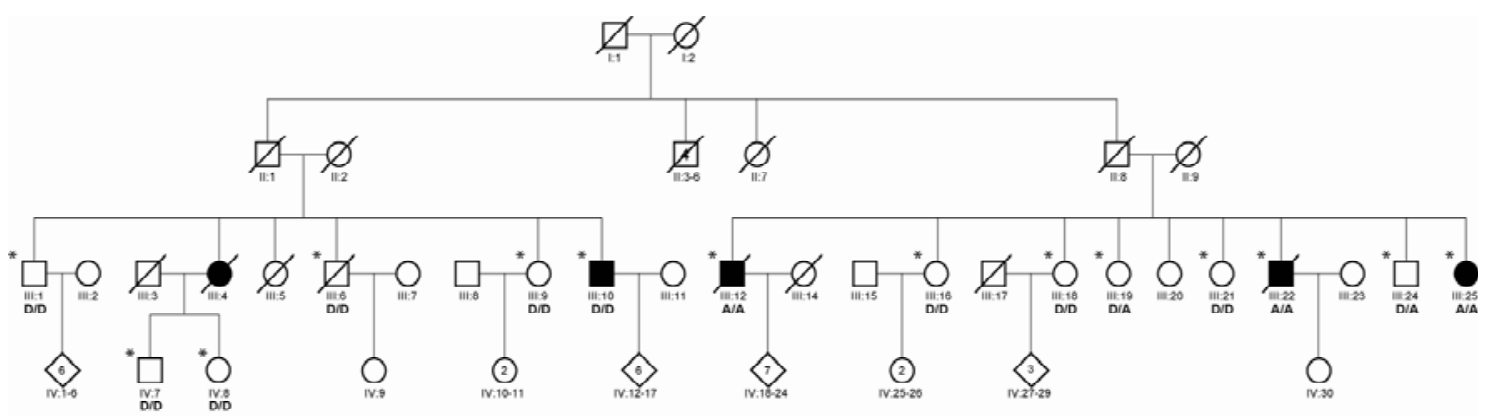




\section{Supplemental figure 2}

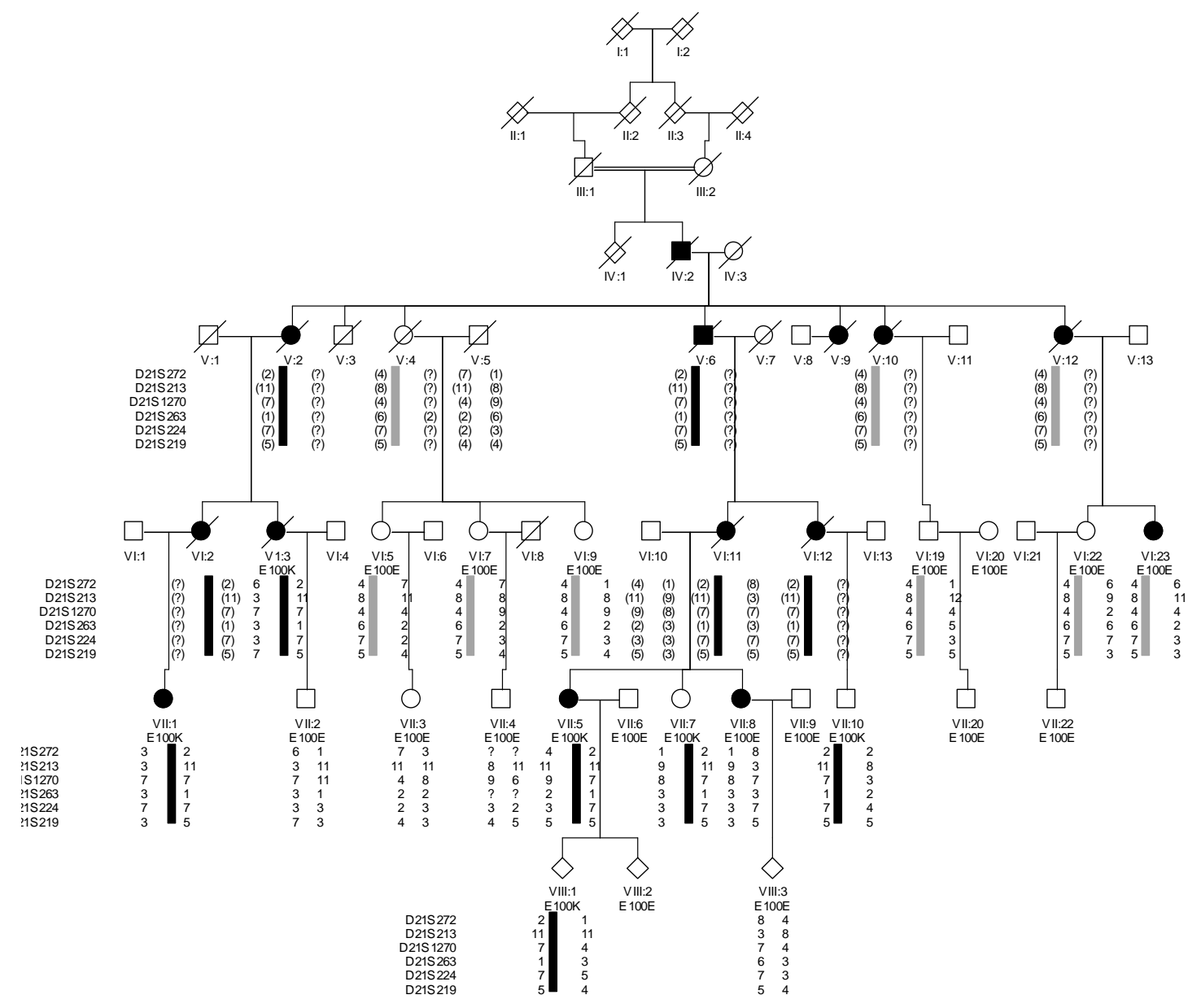


Supplemental figure 3

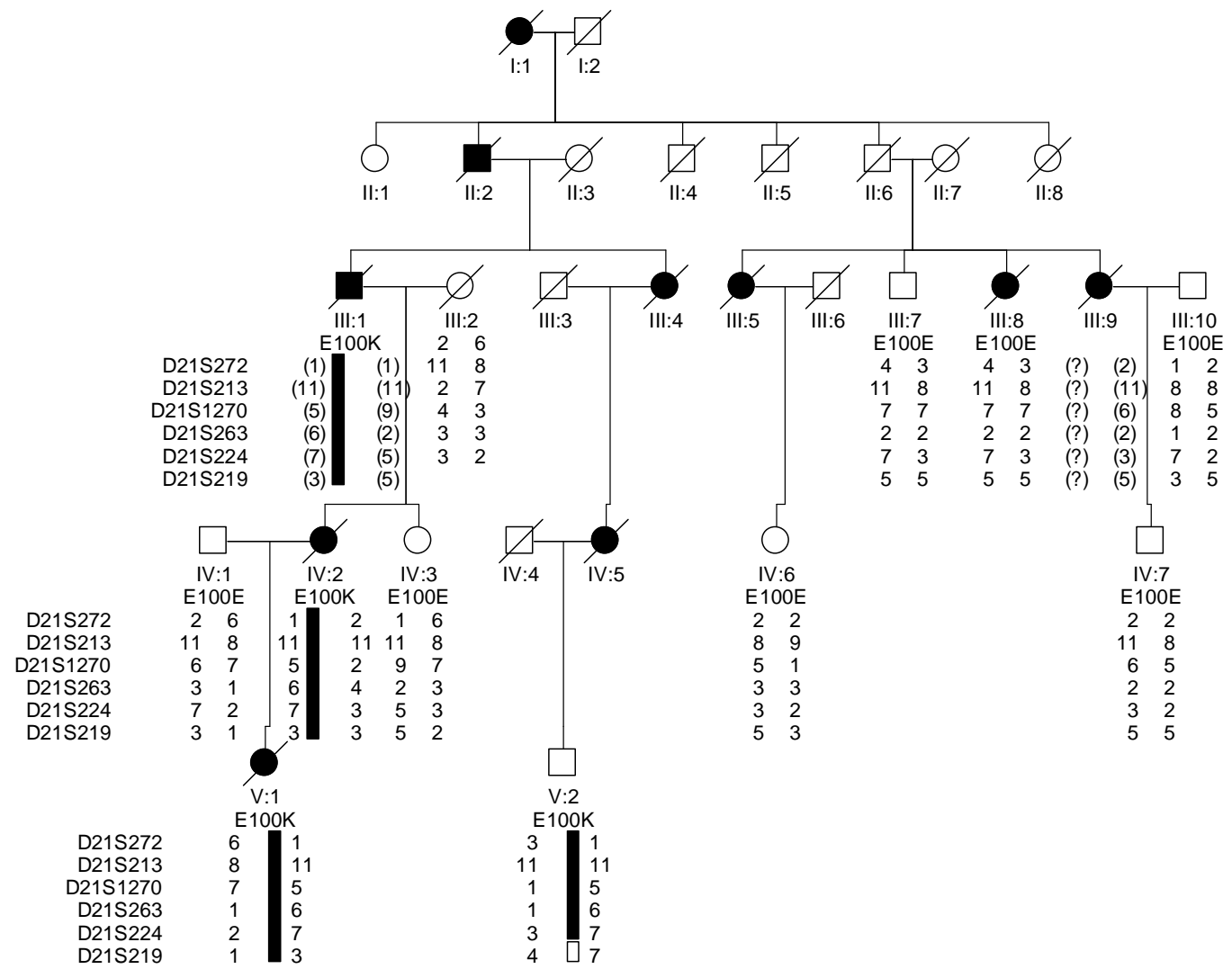



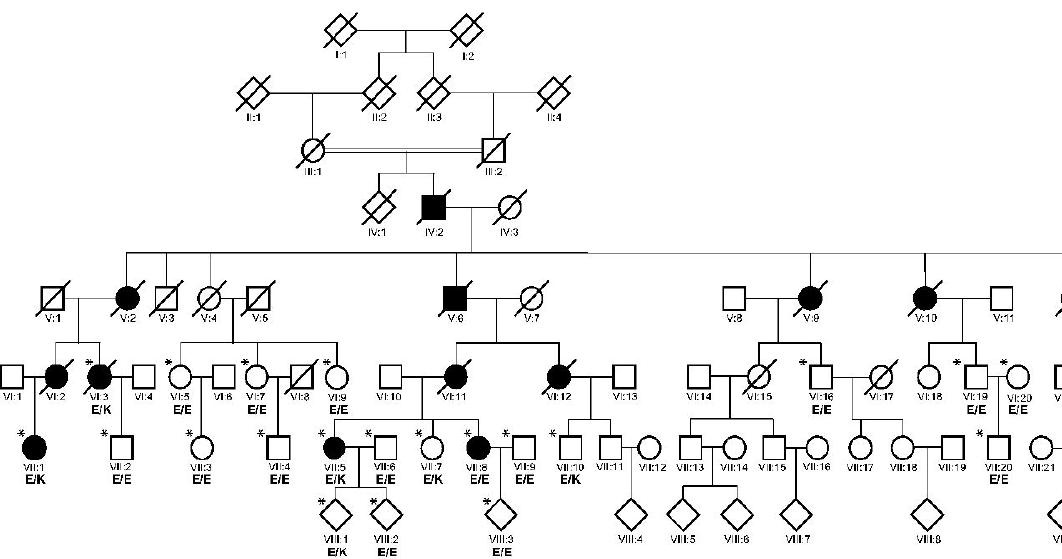


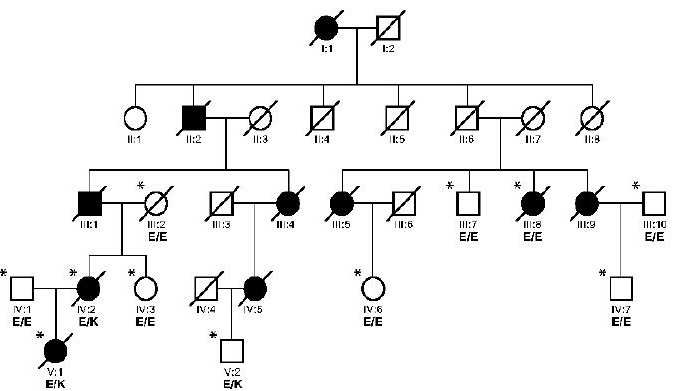




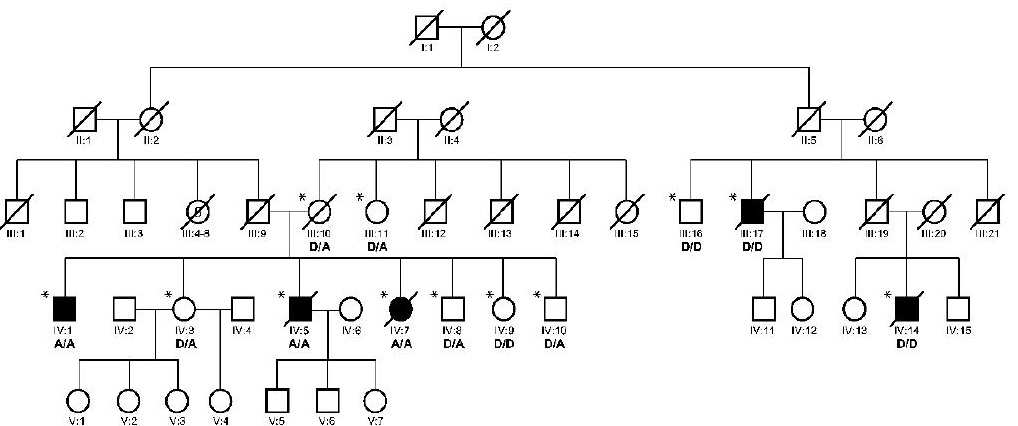




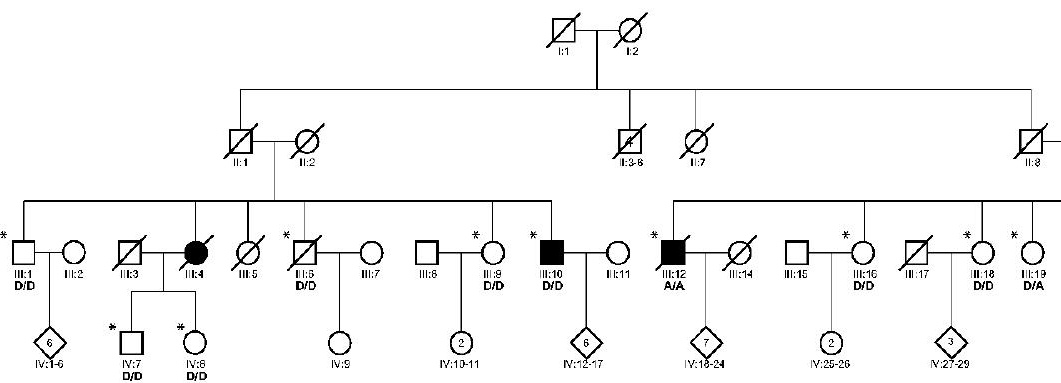

